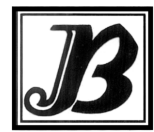

J. Bio-Sci. 29(2): 139-149, 2021 (December)

ISSN 1023-8654

http://www.banglajol.info/index.php/JBS/index

DOI: https://doi.org/10.3329/jbs.v29i2.54962

\title{
CYTOTOXICITY ASSESSMENT OF HERITIERA LITTORALIS (AITON), MADHUCA LONGIFOLIA (KÖNIG) MACBR., NERIUM INDICUM MILL. AND SAPIUM INDICUM (WILLD.) LEAVES ON ARTEMIA SALINA (L.)
}

\author{
N Fatema ${ }^{1}, \mathrm{~K} \mathrm{Hasan}^{2}$, A Islam ${ }^{1}, \mathrm{~N}$ Yasmin $^{3}, \mathrm{M} \mathrm{Nesa}^{3}$ and N Islam ${ }^{3 *}$ \\ 1Institute of Environmental Science, University of Rajshahi, Rajshahi-6205, Bangladesh \\ 2Faculdade de Farmácia da Universidade de Lisboa, Av. Prof. Gama Pinto, 1649-003 Lisboa, Portugal \\ ${ }^{3}$ Department of Zoology, University of Rajshahi, Rajshahi-6205, Bangladesh
}

\begin{abstract}
Petroleum ether, $\mathrm{CHCl}_{3}$ and $\mathrm{CH}_{3} \mathrm{OH}$ extracts of leaves of Heritiera littoralis (Aiton), Madhuca longifolia (König) Macbr., Nerium indicum Mill. and Sapium indicum (Willd.) were subjected to assess cytotoxicity against Artemia salina (L.) nauplii. The petroleum ether extract of $H$. littoralis leaves showed $L C_{50}$ values 273.77, 97.27, 51.60, 37.12, 14.60 and $12.59 \mathrm{ppm}$ after 12, 18, 24, 30, 36 and $42 \mathrm{~h}$; the $\mathrm{CHCl}_{3}$ extract showed $\mathrm{LC}_{50}$ values $733.25,105.51,40.72$ and $18.20 \mathrm{ppm}$ after $6,12,18$ and $24 \mathrm{~h}$ whereas $\mathrm{CH}_{3} \mathrm{OH}$ extract showed 73.05, 30.62, 24.56, 20.85, 16.21 and $6.71 \mathrm{ppm}$ after 6, 12, 18, 24, 30 and $36 \mathrm{~h}$ of exposure respectively. The petroleum ether extract of $M$. longifolia leaves possess $L_{50}$ values 259.35 , 115.17, 56.84 and 8.73 ppm after 12, 18, 24 and $30 \mathrm{~h}$; the $\mathrm{CHCl}_{3}$ extract possess $\mathrm{LC}_{50}$ values 585.43 , 205.86, 112.74, 75.62, 52.84and 47.34 ppm after 12, 18, 24, 30, 36 and $42 \mathrm{~h}$ but $\mathrm{CH}_{3} \mathrm{OH}$ extract possess $\mathrm{LC}_{50}$ values 185.87, 60.70, 30.11 and $15.39 \mathrm{ppm}$ after 12, 18, 24 and $30 \mathrm{~h}$ of exposure respectively. The petroleum ether extract of $N$. Indicum leaves recorded $L C_{50}$ values 249.82, 146.07, 80.23, 54.21 and 40.19 ppm after 18, 24, 30, 36 and $42 \mathrm{~h}$; the $\mathrm{CHCl}_{3}$ extract gave $\mathrm{LC}_{50}$ values 36.13 , 21.72, 19.03, 16.81 and $16.34 \mathrm{ppm}$ after $12,18,24,30$ and $36 \mathrm{~h}$ but $\mathrm{CH}_{3} \mathrm{OH}$ extract recorded $\mathrm{LC}_{50}$ values $394.90,129.69,81.50,73.10$ and $37.51 \mathrm{ppm}$ after 18, 24, 30, 36 and $42 \mathrm{~h}$ of exposure respectively. Similarly, the petroleum ether extract of $S$. indicum leaves showed LC 50 values 24.79 , 13.18 and $4.61 \mathrm{ppm}$ after 12,18 and $24 \mathrm{~h}$; the $\mathrm{CHCl}_{3}$ extract were 50.45, 42.64, 21.20 and $14.93 \mathrm{ppm}$ after 18, 24, 30 and $36 \mathrm{~h}$ of exposure and the $\mathrm{CH}_{3} \mathrm{OH}$ extract showed $\mathrm{LC}_{50}$ values 306.37, 217.18, 149.38, 73.52, 54.45 and $22.91 \mathrm{ppm}$ after 12, 18, 24, 30, 36 and $42 \mathrm{~h}$ of exposure respectively. The intensity of efficacy of the extracts could be arranged in the following descending order of $S$. indicum (petroleum etroleum ether extract) $>H$. littoralis $\left(\mathrm{CH}_{3} \mathrm{OH}\right.$ extract) $>M$. longifolia (petroleum ether extract) $>N$. indicum $\left(\mathrm{CHCl}_{3}\right.$ extract).
\end{abstract}

Key words: Artemia salina, Cytotoxicity, Heritiera littoralis, Madhuca longifolia, Nerium indicum, Sapium indicum, Plant extracts

\section{Introduction}

The plant Heritiera littoralis (Aiton) (Malvaceae) has medicinal properties and various traditional uses. It has anti-cancer (Ioannou et al. 2009), anti-inflammatory (Tewtrakul et al. 2010), antifungal (Bandaranayake 2002), antibacterial (Islam 2017) and larvicidal (Ali et al. 2012) properties. It has also been used to control mosquitoes and as a piscicide (Pattanaik et al. 2008, Bandaranayake 2002). Madhuca longifolia (König) Macbr. (Sapotaceae) has many beneficial uses and ethnomedicinal importance. It has antidiabetic and anti-

*Author for correspondence: n_islamm@yahoo.com 
inflammatory properties (Ghosh et al. 2009, Dahake et al. 2010), antifungal and antioxidant properties (Prashanth et al. 2010). It also has good larvicidal and ovicidal activities (Banerji et al. 1985). Nerium indicum Mill. (Apocynaceae) leaves have been applied externally in the treatment of scabies and to reduce swellings. The leaves and the flowers are cardiotonic, diaphoretic, diuretic, emetic, expectorant and sternutatory (Jawarkar et al. 2012). Leaves and bark are treated as insecticide, rat poison and parasitic (Dey and Chaudhuri 2014, Url 1. 2019). The leaves also exhibited antioxidant (Vinayagam and Sudha 2011), analgesic (Shah et al. 2011) and antiviral (Rajbhandari et al. 2001) activities. Sapium indicum (Willd.) is an evergreen tree of Euphorbiaceae. Fruits of this plant have a significant antimicrobial (Chumkaew et al. 2003, Silprasit et al. 2011), insecticidal (Khanam et al. 2008), pesticidal (Khalil 1984, Chowdhury 1996) and antifungal (Miah et al. 1990) activities. Artemia salina (L.) (Anostraca: Artemiidae) is commonly known as Brine shrimp belongs to a genus of crustaceans (Crayfish). It is one of the standard organisms for testing the toxicity of chemicals (Ruebhart et al. 2008). The females of this crustacean can produce eggs either as a result of mating or via parthenogenesis. Eggs hatch into nauplii that are about $0.5 \mathrm{~mm}$ in length. Eggs can remain in a dormant state as cysts. These cysts can last for several years and will hatch when they are placed in saltwater (Sara 2012). The present investigation was designed to the screening of the crude extracts of the above plants on cytotoxicity of $A$. salina.

\section{Materials and Methods}

\section{Collection and preparation of the tested plants}

The leaves of the selected plants $H$. littoralis, $M$. longifolia, $N$. indicum and $S$. indicum were collected from Khulna, Bagerhat and Rajshahi Districts of Bangladesh. The leaves of the collected plant were cut into small pieces, spread out in wooden trays and kept in a well-ventilated room to dry them at room temperature. Well dried leaves were ground to powder with a blender, weighed, kept in separate conical flasks and then extracted with a sufficient amount of solvent (petroleum ether, $\mathrm{CHCl}_{3}$ or $\left.\mathrm{CH}_{3} \mathrm{OH}\right)(100 \mathrm{~g} \times 300 \mathrm{ml} \times 2$ times) for $48 \mathrm{~h}$. Filtration was done by Whatman No. 40 filter paper and after evaporation, the extracts were collected in glass vials and kept in a cool place at $4^{\circ} \mathrm{C}$ with appropriate labeling.

\section{Hatching of Brine shrimp cysts}

Fresh cysts in vials were purchased from the Pet and Aquarium market of Nilkhet, Dhaka, Bangladesh. Eggs of Brine shrimp were hatched in an aquarium using 1 liter of $1 \mathrm{M} \mathrm{NaCl}$ brine solution $(\mathrm{pH} 8.5)$. The eggs were incubated for $48 \mathrm{~h}$ under fluorescent light and the nauplii were hatched within $24-36 \mathrm{~h}$ at $30-35^{\circ} \mathrm{C}$. After hatching, the nauplii were transferred to test tubes. Ten nauplii were transferred to each tube. $1.5 \mathrm{ml} \mathrm{NaCl}$ solution was added to each test tube.

\section{Test sample preparation and Brine shrimp lethality test}

Test samples at different concentrations were considered as doses prepared in test tubes by addition of a calculated amount of DMSO (dimethylsulfoxide). Then water was added to fill the pre-marked (up to $10 \mathrm{ml}$ ) test tubes with the help of a pipette. The nauplii were counted by visual inspection and were released in test tubes containing $10 \mathrm{ml}$ of water and the test tubes were kept at room temperature along with a control batch. Observation of mortality was made after $6,12,18,24,30,36$ and $42 \mathrm{~h}$ of exposure. 
Plant extract solutions at different concentrations (for all three extracts of $H$. littoralis leaves in petroleum ether 90.67, 64.67, 53.33, 34.33 and 21.00 ppm; in $\mathrm{CHCl}_{3} 168.67,101.00,53.33,23.33$ and $12.50 \mathrm{ppm}$ and in $\mathrm{CH}_{3} \mathrm{OH}$ were $200.00,100.00,50.00,25.00$ and $12.50 \mathrm{ppm}$. For M. Iongifolia in Petroleum ether were $169.00,127.00,101.00,85.00$ and $43.00 \mathrm{ppm}$; in $\mathrm{CHCl}_{3} 179.00,119.00,89.00,59.00$ and $44.00 \mathrm{ppm}$ and in $\mathrm{CH}_{3} \mathrm{OH}$ were $200.00,100.00,50.00,25.00$ and $12.50 \mathrm{ppm}$. For $N$. indicum in Petroleum ether 200.00, 100.00, 50.00, 25.00 and 12.50 ppm; in $\mathrm{CHCl}_{3} 180,90,45,22.5$ and 11.25 and in $\mathrm{CH}_{3} \mathrm{OH}$ were 100.00, $50.00,25.00,12.50$ and $6.25 \mathrm{ppm}$. The doses for all the three extracts of $S$. indicum leaves were in Petroleum ether 100.00, 50.00, 25.00, 12.50 and 6.25 ppm; in $\mathrm{CHCl}_{3}$ 174.00, 87.00, 43.50, 21.75 and 10.86 ppm and $\mathrm{CH}_{3} \mathrm{OH} 100.00,50.00,25.00,12.50$ and 6.25 ppm in artificial seawater containing $1 \%$ DMSO (v/v) used for this assay. Ten nauplii were used in each of the test tubes and three replicates were used for each concentration. Test tubes later had $1 \mathrm{ml}$ of NaCl solution added to them. After $6,12,18,24,30,36$ and $42 \mathrm{~h}$ incubation, the number of survivors and count of the dead nauplii was done using a dissection microscope and the percentage of the mortality $(\% \mathrm{M})$ for each of the doses was calculated as compared with the control. DMSO (1\%) served as the negative control and the final concentration of DMSO in the assay volume was kept always below $1 \%$ to prevent possible false effects originating from DMSO toxicity. $\mathrm{LC}_{50}$ value is the concentration of the sample required to kill $50 \%$ of the Brine shrimp population and this was calculated from the plot of \% inhibition against the log concentration of sample extract. According to Meyer et al. (1982), an $\mathrm{LC}_{50}$ value of less than $1 \mathrm{mg} / \mathrm{ml}$ is considered toxic while an $\mathrm{LC}_{50}$ value greater than $1 \mathrm{mg} / \mathrm{ml}$ is deemed to be non-toxic.

\section{Statistical analysis}

In this study, recorded values were expressed as mean \pm standard error of the mean (SEM). In the cytotoxicity study, $L_{50}$-values and $95 \%$ of confidence intervals were determined. The mortality (\%) was observed using Abbott's formula (Abbott 1925) $\left[\mathrm{Pr}_{r}=\left(\mathrm{P}_{0}-\mathrm{P}_{\mathrm{c}}\right) /\left(100-\mathrm{P}_{\mathrm{c}}\right) \times 100\right.$; Here, $\mathrm{Pr}_{\mathrm{r}}=$ corrected mortality $(\%), \mathrm{P}_{0}=$ observed mortality (\%) and $\mathrm{P}_{\mathrm{c}}=$ mortality in the control (\%)] and subjected to probit analysis (Finney 1947, Busvine 1971).

\section{Results}

\section{Brine shrimp cytotoxicity}

The cytotoxic activity of the test plants had been shown in Table 1. All the tested plants showed promising cytotoxic potentiality against $A$. salina nauplii of the three extracts for each of the plants in different solvents. For $\mathrm{H}$. littoralis [Fig. 1 (a-p): Regression lines] the highest and lowest activity were observed in $\mathrm{CH}_{3} \mathrm{OH}\left(\mathrm{LC}_{50}\right.$ $=6.71 \mathrm{ppm})$ after $36 \mathrm{~h}$ and in $\mathrm{CHCl}_{3}\left(\mathrm{LC}_{50}=733.25 \mathrm{ppm}\right)$ after $6 \mathrm{~h}$ of exposure. For the extracts of $\mathrm{M}$. longifolia [Fig. 2 (a-n): Regression lines] the highest and lowest activities were observed in case of petroleum ether $\left(\mathrm{LC}_{50}=8.73 \mathrm{ppm}\right)$ after $30 \mathrm{~h}$ and in $\mathrm{CHCl}_{3}\left(\mathrm{LC}_{50}=585.43 \mathrm{ppm}\right)$ after $12 \mathrm{~h}$ of exposure. In case of $\mathrm{N}$. indicum [Fig. 3 (a-0): Regression lines] the highest and lowest activity were observed in $\mathrm{CHCl}_{3}\left(\mathrm{LC}_{50}=16.34\right.$ $\mathrm{ppm})$ after $36 \mathrm{~h}$ and in $\mathrm{CH}_{3} \mathrm{OH}\left(\mathrm{LC}_{50}=394.90 \mathrm{ppm}\right)$ after $18 \mathrm{~h}$ of exposure. Finally, the highest and lowest efficacies were observed in petroleum ether $\left(\mathrm{LC}_{50}=4.61 \mathrm{ppm}\right)$ after $24 \mathrm{~h}$ and in $\mathrm{CH}_{3} \mathrm{OH}\left(\mathrm{LC}_{50}=306.37 \mathrm{ppm}\right)$ after $12 \mathrm{~h}$ of exposure in case of $\mathrm{S}$. indicum [Fig. 4 (a-m): Regression lines]. 
According to the intensity of activity, the extracts of the test plants could be arranged in the following descending order: S. indicum (petroleum ether extract) $>H$. littoralis $\left(\mathrm{CH}_{3} \mathrm{OH}\right.$ extract) $>M$. longifolia (petroleum ether extract) $>\mathrm{N}$. indicum $\left(\mathrm{CHCl}_{3}\right.$ extract).

Table 1. $\mathrm{LC}_{50}$ values of the leaf extracts of $H$. littoralis, M. Iongifolia, $N$. indicum and $S$. indicum on Brine shrimp A. salina nauplii

\begin{tabular}{|c|c|c|c|c|c|c|c|c|}
\hline \multirow{2}{*}{$\begin{array}{l}\text { Plant } \\
\text { name }\end{array}$} & \multirow{2}{*}{ Solvent } & \multicolumn{7}{|c|}{$\mathrm{LC}_{50}(\mathrm{ppm})$ at different exposure } \\
\hline & & $6 \mathrm{~h}$ & $12 \mathrm{~h}$ & $18 \mathrm{~h}$ & $24 \mathrm{~h}$ & $30 \mathrm{~h}$ & $36 \mathrm{~h}$ & $42 \mathrm{~h}$ \\
\hline \multirow{3}{*}{ H. littoralis } & $\begin{array}{l}\text { Petroleum } \\
\text { ether }\end{array}$ & - & 273.77(a) & $97.27(b)$ & $51.60(c)$ & $37.12(d)$ & 14.60(e) & $12.59(f)$ \\
\hline & $\mathrm{CHCl}_{3}$ & $733.25(\mathrm{~g})$ & 105.51(h) & $40.72(i)$ & 18.20(j) & - & - & - \\
\hline & $\mathrm{CH}_{3} \mathrm{OH}$ & $73.05(k)$ & $30.62(I)$ & $24.56(\mathrm{~m})$ & 20.85(n) & $16.21(0)$ & $6.71(p)$ & - \\
\hline \multirow{3}{*}{$\begin{array}{l}\text { M. } \\
\text { longifolia }\end{array}$} & $\begin{array}{l}\text { Petroleum } \\
\text { ether }\end{array}$ & - & 259.35(a) & 115.17(b) & $56.84(c)$ & $8.73(d)$ & - & - \\
\hline & $\mathrm{CHCl}_{3}$ & - & $585.43(\mathrm{e})$ & $205.86(f)$ & $112.74(\mathrm{~g})$ & 75.62(h) & $52.84(i)$ & 47.34(j) \\
\hline & $\mathrm{CH}_{3} \mathrm{OH}$ & - & $185.87(k)$ & $60.70(l)$ & $30.11(m)$ & 15.39(n) & - & - \\
\hline \multirow{3}{*}{$\begin{array}{l}N . \\
\text { indicum }\end{array}$} & $\begin{array}{l}\text { Petroleum } \\
\text { ether }\end{array}$ & - & - & 249.81(a) & 146.07(b) & $80.23(c)$ & $54.21(d)$ & 40.19(e) \\
\hline & $\mathrm{CHCl}_{3}$ & - & $36.13(f)$ & $21.72(\mathrm{~g})$ & 19.03(h) & 16.81(i) & 16.34(j) & - \\
\hline & $\mathrm{CH}_{3} \mathrm{OH}$ & - & - & $394.90(k)$ & $129.69(I)$ & $81.50(\mathrm{~m})$ & $73.10(n)$ & $37.51(0)$ \\
\hline \multirow{3}{*}{ S. indicum } & $\begin{array}{l}\text { Petroleum } \\
\text { ether }\end{array}$ & - & 24.79(a) & 13.18(b) & 4.61(c) & - & - & - \\
\hline & $\mathrm{CHCl}_{3}$ & - & - & $50.45(d)$ & 42.64(e) & $21.20(f)$ & $14.93(\mathrm{~g})$ & - \\
\hline & $\mathrm{CH}_{3} \mathrm{OH}$ & - & $306.37(h)$ & 217.18(i) & 149.38(j) & 73.52(k) & $54.45(I)$ & $22.91(\mathrm{~m})$ \\
\hline
\end{tabular}

Respective regression lines of the LC 50 values in Table 1 are given in Fig. 1 (a-p), Fig. 2 (a-n), Fig. 3 (a-o) and Fig. 4 (a-m) below. 


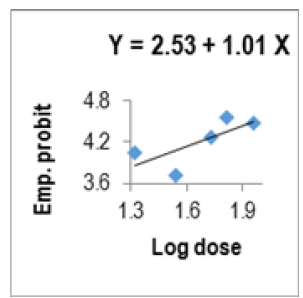

a) Pet. ether extract after $12 \mathrm{~h}$ of exposure.

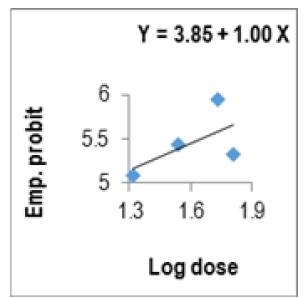

e) Pet. ether extract after $36 \mathrm{~h}$ of exposure.
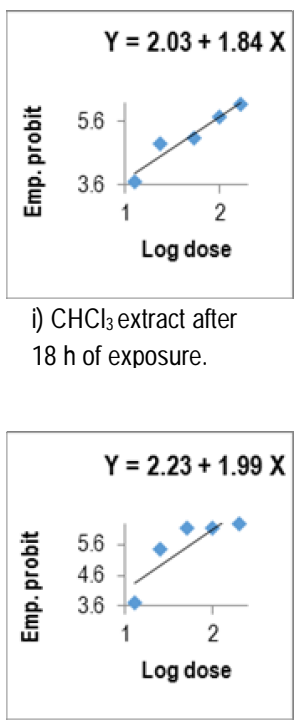

m) $\mathrm{CH}_{3} \mathrm{OH}$ extract after $18 \mathrm{~h}$ of exposure.

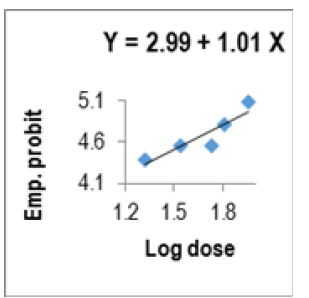

b) Pet. ether extract after $18 \mathrm{~h}$ of exposure.

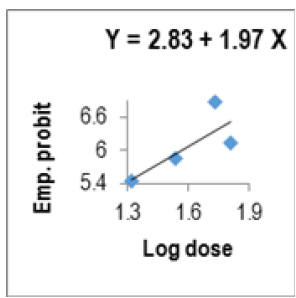

f) Pet. ether extract after $42 \mathrm{~h}$ of exposure.
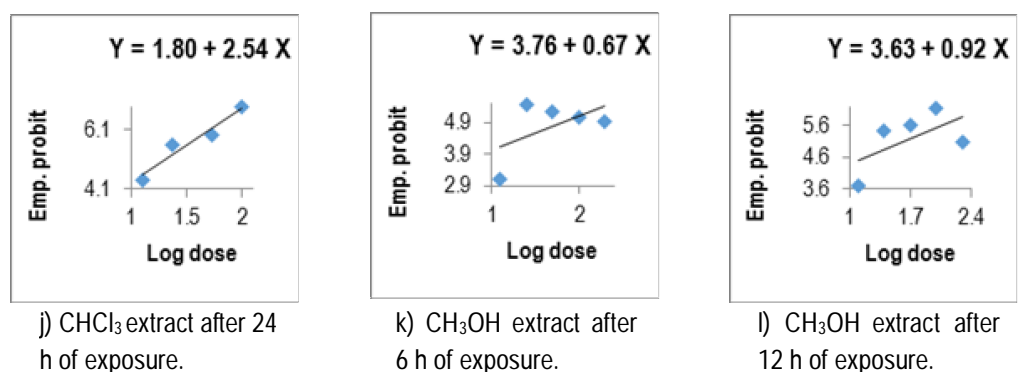

c) Pet. ether extract after $24 \mathrm{~h}$ of exposure.

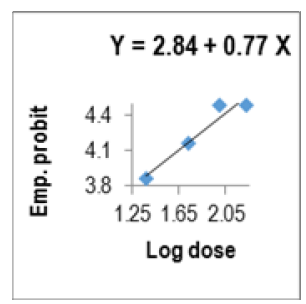

g) $\mathrm{CHCl}_{3}$ extract after $6 \mathrm{~h}$ of exposure.

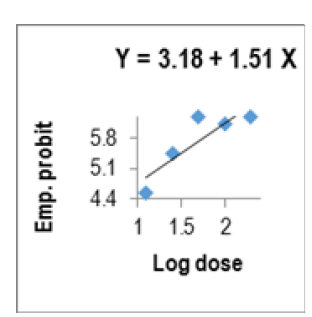

n) $\mathrm{CH}_{3} \mathrm{OH}$ extract after $24 \mathrm{~h}$ of exposure.

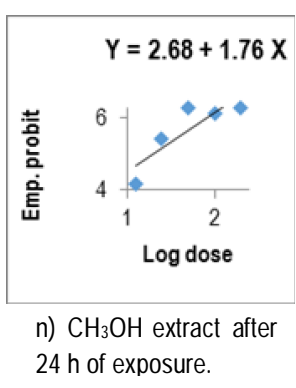

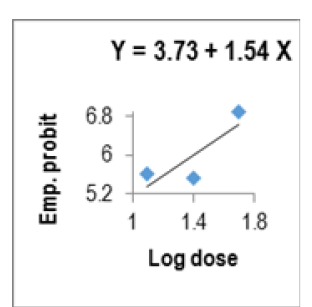

p) $\mathrm{CH}_{3} \mathrm{OH}$ extract after $36 \mathrm{~h}$ of exposure.

Fig. 1 (a-p): Regression lines of $H$. littoralis extracts against $A$. salina nauplii at different hours of exposure. 


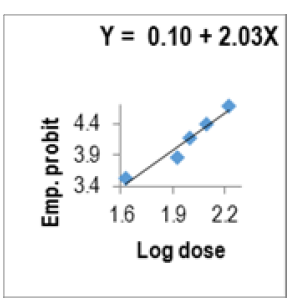

a) Pet. ether extract after $12 \mathrm{~h}$ of exposure.

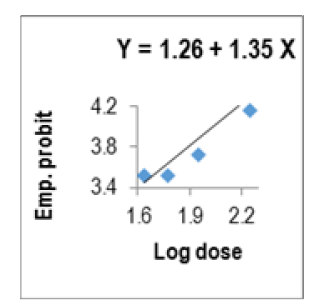

e) $\mathrm{CHCl}_{3}$ extract after $12 \mathrm{~h}$ of exposure.
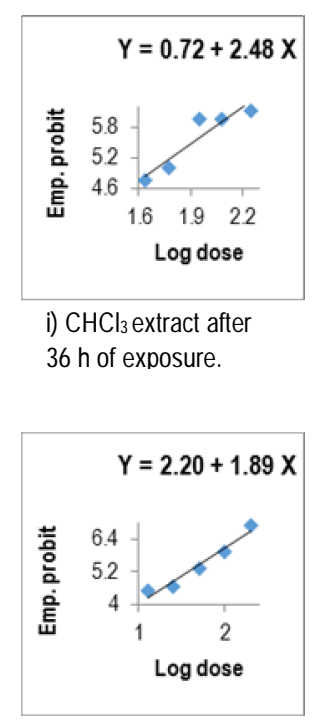

m) $\mathrm{CH}_{3} \mathrm{OH}$ extract after $24 \mathrm{~h}$ of exposure.

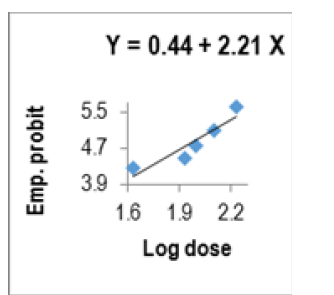

b) Pet. ether extract after $18 \mathrm{~h}$ of exposure.

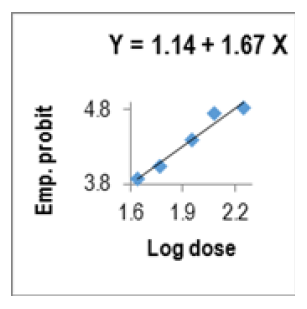

f) $\mathrm{CHCl}_{3}$ extract after $18 \mathrm{~h}$ of exposure.
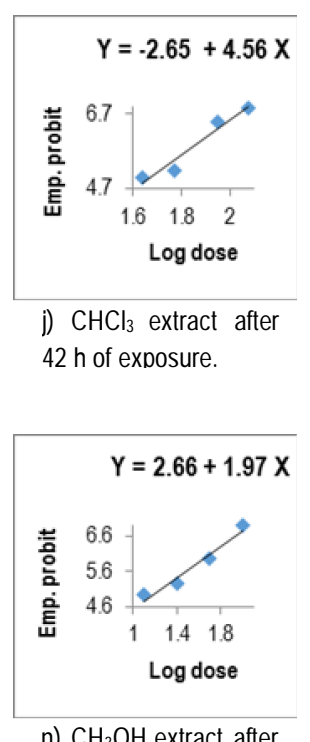

n) $\mathrm{CH}_{3} \mathrm{OH}$ extract after $30 \mathrm{~h}$ of exposure.

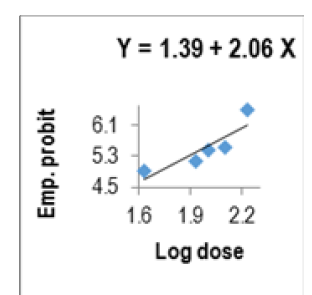

c) Pet. ether extract after $24 \mathrm{~h}$ of exposure.

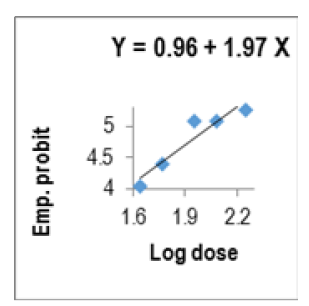

g) $\mathrm{CHCl}_{3}$ extract after $24 \mathrm{~h}$ of exposure.

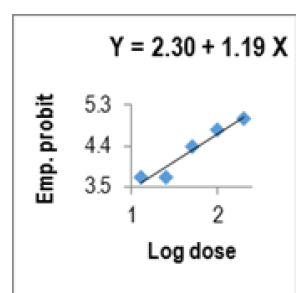

k) $\mathrm{CH}_{3} \mathrm{OH}$ extract after $12 \mathrm{~h}$ of exposure.

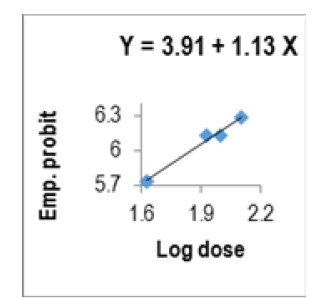

d) Pet. ether extract after $30 \mathrm{~h}$ of exposure.

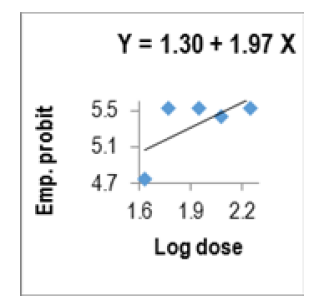

h) $\mathrm{CHCl}_{3}$ extract after $30 \mathrm{~h}$ of exposure.

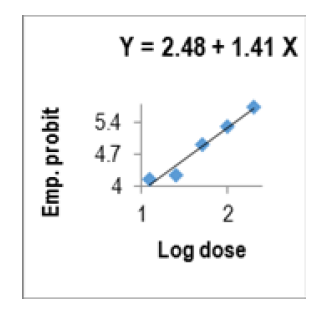

l) $\mathrm{CH}_{3} \mathrm{OH}$ extract after $18 \mathrm{~h}$ of exposure.

Fig. 2 (a-n): Regression lines of $M$. longifolia extracts against $A$. salina nauplii at different hours of exposure. 


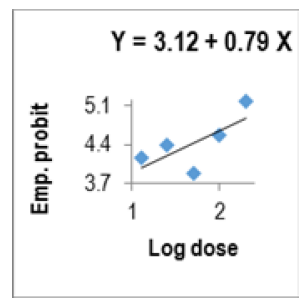

a) Pet. ether extract after $18 \mathrm{~h}$ of exposure.

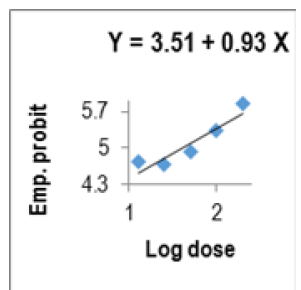

e) Pet. ether extract after $42 \mathrm{~h}$ of exposure.
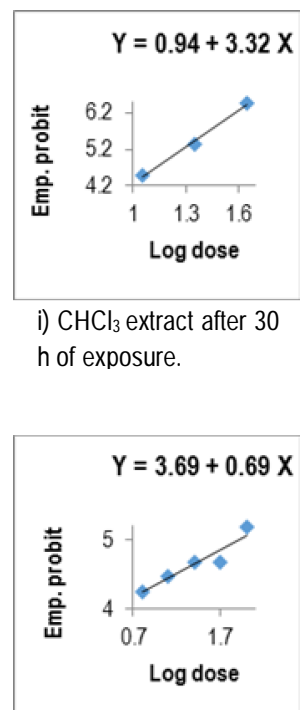

m) $\mathrm{CH}_{3} \mathrm{OH}$ extract after $30 \mathrm{~h}$ of exposure.

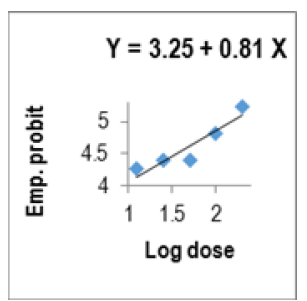

b) Pet. ether extract after $24 \mathrm{~h}$ of exposure.

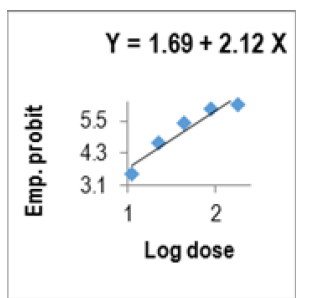

f) $\mathrm{CHCl}_{3}$ extract after 12 $\mathrm{h}$ of exposure.
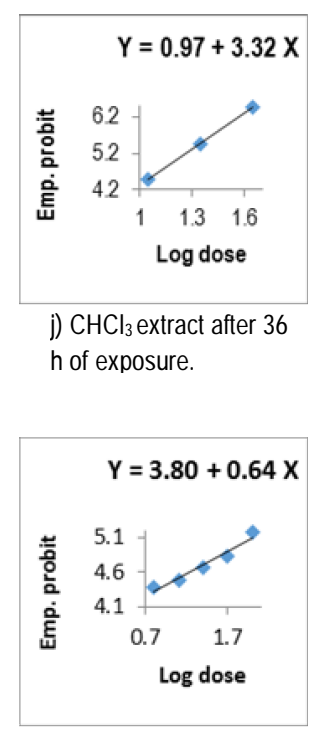

n) $\mathrm{CH}_{3} \mathrm{OH}$ extract after $36 \mathrm{~h}$ of exposure.

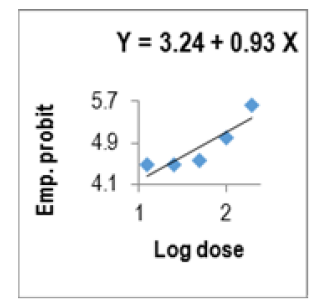

c) Pet. ether extract after $30 \mathrm{~h}$ of exposure.

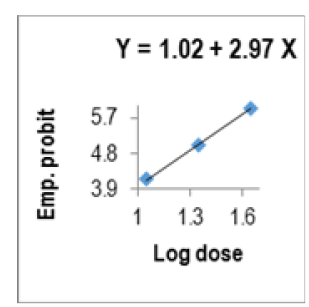

g) $\mathrm{CHCl}_{3}$ extract after $18 \mathrm{~h}$ of exposure.

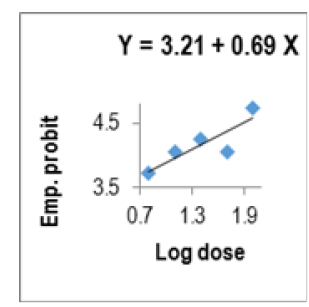

k) $\mathrm{CH}_{3} \mathrm{OH}$ extract after 18 of exposure.

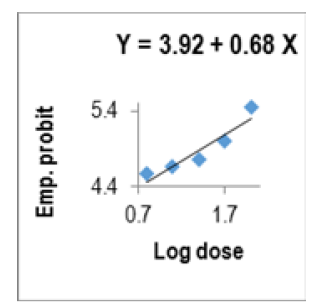

o) $\mathrm{CH}_{3} \mathrm{OH}$ extract after $42 \mathrm{~h}$ of exposure.

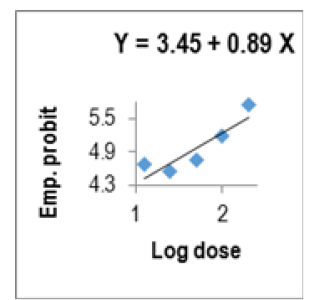

d) Pet. ether extract after $36 \mathrm{~h}$ of exposure.
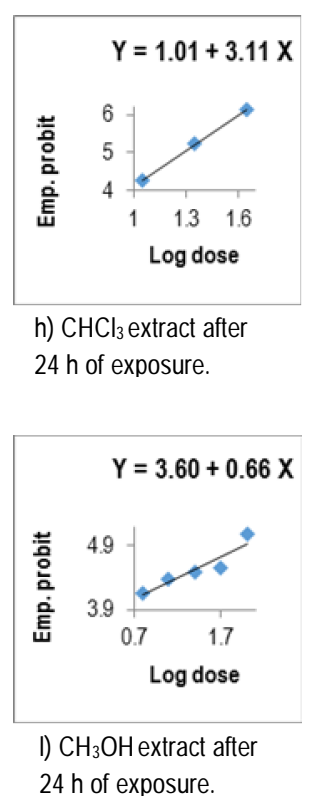

$24 \mathrm{~h}$ of exposure.

Fig. 3 (a-o): Regression lines of $N$. indicum extracts against $A$. salina nauplii at different hours of exposure. 


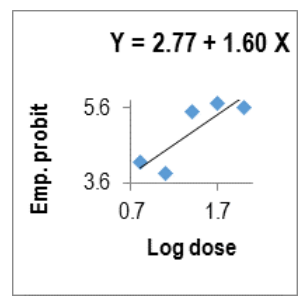

a) Pet. ether extract after $12 \mathrm{~h}$ of exposure.

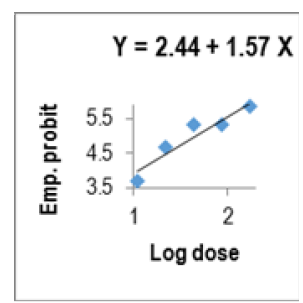

e) $\mathrm{CHCl}_{3}$ extract after $24 \mathrm{~h}$ of exposure.
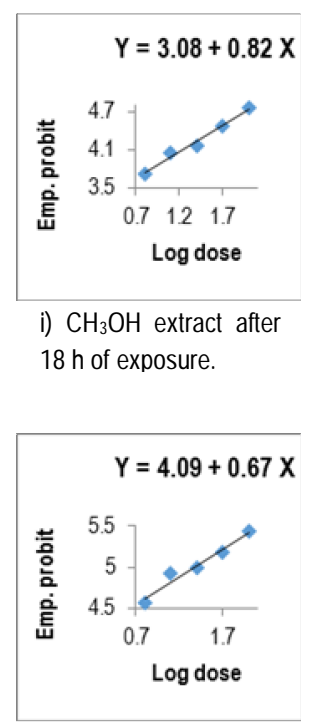

m) $\mathrm{CH}_{3} \mathrm{OH}$ extract after $42 \mathrm{~h}$ of exposure.

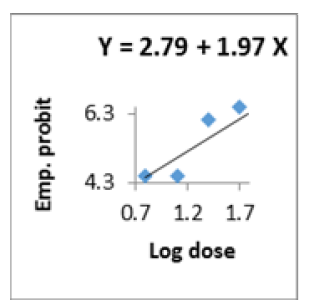

b) Pet. ether extract after $18 \mathrm{~h}$ of exposure.

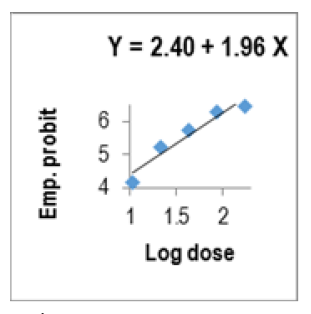

f) $\mathrm{CHCl}_{3}$ extract after 30 $\mathrm{h}$ of exposure.

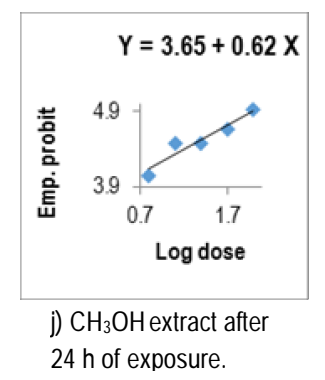

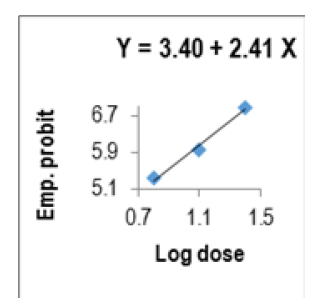

c) Pet. ether extract after $24 \mathrm{~h}$ of exposure.
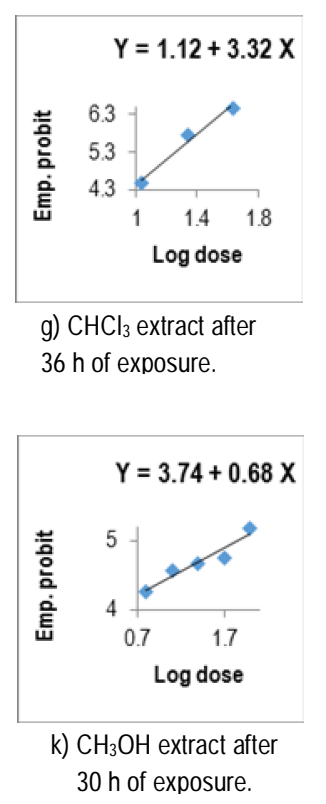

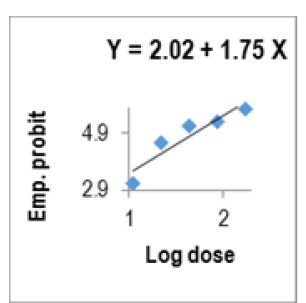

d) $\mathrm{CHCl}_{3}$ extract after 18 $\mathrm{h}$ of exposure.
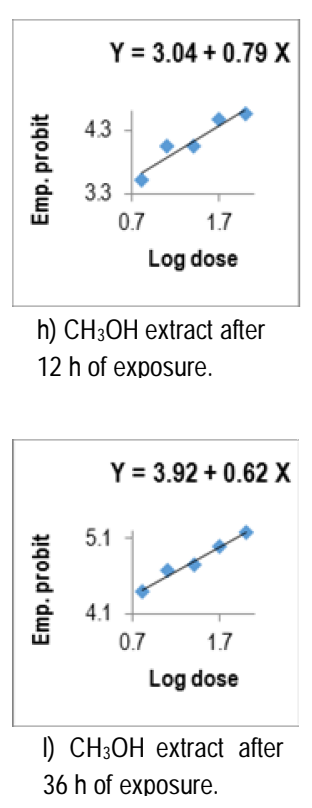

Fig. $4(a-m)$ : Regression lines of $S$. indicum extracts against $A$. salina nauplii at different hours of exposure. 


\section{Discussion}

The findings of this investigation on the four medicinal plants $H$. littoralis, M. Iongifolia, $N$. indicum and S. indicum have got support from the works of previous researchers. Patra and Mohanta (2014) reported the antimicrobial activities of the mangrove plant $H$. littoralis. Salini (2015) found this plant used as a mosquito control agent, cure for diarrhoea and as a fish toxicant. Bark, leaves, roots and stems are used by rural people for the treatment of diabetes and goitre, gastrointestinal disorders, skin diseases and hepatic disorders (Ali et al. 2011, Hossain et al. 2013, Patra and Thatoi 2013). The potentiality of the alcoholic extract of leaves and flowers of $M$. longifolia are revealed significant antibacterial activities against Staphylococcus aureus, Bacillus subtilis, Escherichia coli, Pseudomonas aeruginosa and antifungal activities against Aspergillus oryzae and Aspergillus niger (Kalaivani and Jagadeesan 2013). Purohit et al. (2012) reported the immunomodulatory activity of $M$. longifolia and reported ethanolic extract enhances the humoral and cellmediated immune response in Swiss albino mice. Chetwani et al. (2017) reported the leaves extracts of $N$. indicum were found to be active against the bacteria Pseudomonas aeruginosa. Reddy (2010) reported the alcoholic extract of $N$. indicum leaves inhibited the growth rate of some bacterial spp. Staphylococcus aureus, Candida albicans and some fungi Aspergillus niger, Mucor., Rhizopus and Penicillium even at lower concentrations. Leaves of this plant exhibited antioxidant (Vinayagam and Sudha 2011), antiviral (Rajbhandari et al. 2001) and analgesic (Shah et al. 2011) properties. Very strong support was reported from previous researchers on the potentiality of the plant S. indicum. Azis et al. (2015) described that S. indicum has good wound healing properties. They also mentioned the cytotoxic effects of $S$. indicum. The findings of Rahman and Monowar (2014) revealed that the petroleum ether extract of the fruit is more toxic than organochlorine compounds. The intravenous and oral administration of the extract kills laboratory animals, rats and mice that can be used as an alternative source of bio-pesticides (Rahman and Monowar 2014). Thus, the test plants $H$. littoralis, $M$. longifolia, $N$. indicum and $S$. indicum need further investigations to be attempted to reveal their total usefulness in the field of health and pest control technology.

\section{Conclusion}

By analyzing the results of cytotoxicity tests of $H$. littoralis, $M$. longifolia, $N$. indicum and $S$. indicum leaf extracts in petroleum ether, $\mathrm{CHCl}_{3}$ and $\mathrm{CH}_{3} \mathrm{OH}$ against $A$. salina it could be concluded that the plants have some bioactive potentials and that could be used in controlling pest organisms in aquatic media. Further studies on isolation and identification of the biologically active compounds of these plants are necessary.

\section{Acknowledgements}

The authors are grateful to the University Grants Commission (UGC) of Bangladesh for a research grant, the Director of the Institute of Environmental Science and the Chairman of the Department of Zoology, University of Rajshahi, Bangladesh for providing laboratory facilities.

\section{References}

Abbott WS (1925). A method of computing the effectiveness of an insecticide. Journal of Economic Entomology, 18(2): 265-267.

Ali M, Nahar K, Sintaha M, Khaleque HN, Jahan FI, Biswas KR, Swarna A, Monalisa MN, Jahan R and Rahmatullah M (2011). An evaluation of antihyperglycemic and antinociceptive effects of methanol extract of Heritiera fomes BuchHam. (Sterculiaceae) barks in Swiss albino mice. Advances in Natural and Applied Sciences, 5(2): 116-121. 
Ali MS, Ravikumar S and Beula JM (2012). Spatial and temporal distribution of mosquito larvicidal compounds in Mangroves. Asian Pacific Journal of Tropical Disease, 2(5): 401-404.

Azis HA, Taher M, Susanti D and Zakaria ZA (2015). In vitro wound healing activity of Sapium indicum Willd. leaf extracts. African Journal of Traditional and Complementary Alternative Medicine, 12(2): 126-132.

Bandaranayake WM (2002). Bioactivities, bioactive compounds and chemical constituents of mangrove plants. Wetlands Ecology and Management, 10: 421-452.

Banerji R, Misra G and Nigam SK (1985). Madhuca indica leaf saponin and its biological activity. Fitoterpia, 56(3): 186-188.

Busvine JR (1971). A Critical Review of the Techniques for Testing Insecticides. Commonwealth Agricultural Bureau, London. pp. 345.

Chetwani K, Agnihotri DRK and Chaturvedi DP (2017). Aqueous, acetone and ethanolic extract of Nerium indicum L. as potential antibacterial agent against Pseudomonas aeruginosa. International Journal of Applied Environmental Sciences, 12(9): 1721-32.

Chowdhury R (1996). Piscicidal effects of some indigenous plant extracts on Heteroptneusts fossilis (Bloch) and Anabas testudineus (Bloch). MSc Thesis, University of Chittagong, Bangladesh.

Chumkaew P, Karalai C, Ponglimanont $C$ and Chantrapromma K (2003). Antimycobacterial activity of phorbol esters from the fruits of Sapium indicum. Journal of Natural Products, 66: 4540-43.

Dahake AP, Chakma CS, Joshi D, Chakma RC and Tripathi A (2010). Antioxidant activity of methanolic extract of Madhuca longifolia bark. Journal of Pharmacy Research, 3(8): 1709-11.

Dey $P$ and Chaudhuri TK (2014). Pharmacological aspects of Nerium indicum Mill: A comprehensive review. Pharmacognosy Review, 8(16): 156-162.

Finney DJ (1947). Probit Analysis: A Statistical Treatment of the Sigmoid Response Curve. Cambridge University Press, London. pp. 333.

Ghosh R, Dhande I, Kakade VM, Vohra RR, Kadam VJ and Mehra SB (2009). Antihyperglycemic activity of Madhuca longifolia in alloxan-induced diabetic rats. The Internet Journal of Pharmacology, 6(2): 354-358.

Hossain MA, Panthi S, Asadujjaman M, Khan SR, Ferdous F and Sadhu SK (2013). Phytochemical and pharmacological assessment of the ethanol leaves extract of Heritiera fomes Buch. Ham. (Family- Sterculiaceae). Journal of Porphyrins and Phthalocyanines, 2: 95-101.

Ioannou E, Abdel-Razik AF, Zervou M, Christofidis D, Alexi X, Vagias C, Alexis MN and Roussis V (2009). Epidioxysterols from the gorgonian Eunicella cavolini and the ascidian Trididemnum inarmatum: Isolation and evaluation of their antiproliferation activity. Steroids, 74: 73-80.

Islam MA (2017). Evaluation of antioxidant activity and determination of total phenolic content of leaves extract of Heritiera littoralis (Sundari tree). MS Thesis, Daffodil International University, Bangladesh.

Jawarkar AG, Shrirao AV, Mohale DS, Chandewar AV, Marathe SJ and Mahajan PG (2012). Brief review on medicinal potential of Nerium indicum. International Journal of Institutional Pharmacy and Life Sciences, 2(2): 521-527.

Kalaivani M and Jegadeesan M (2013). Antimicrobial activity of alcoholic extract of leaves and flowers of Madhuca longifolia. International Journal of Scientific and Research Publications, 3(5): 1-3.

Khalil MI (1984). Study on the piscicidal property of the indigenous Sapium indicum fruits (Fam. Euphorbiaceae). MSc Thesis, University of Dhaka, Bangladesh.

Khanam LAM, Khan AR, Khalequzzaman M and Rahman SM (2008). Effect of Sapium indicum, Thevetia neriifolia and Jatropha gossypifolia seed extract on the fecundity and fertility of Tribolium castaneum and Tribolium confusum. Bangladesh Journal of Scientific and Industrial Research, 43(1): 55-66.

Meyer BN, Ferrigni NR, Putnam JE, Jacobsen LB, Nichols DE, Nicols JL and McLaughlin (1982). Brine shrimp: A convenient general bioassay for active plant constituents. Planta Medica, 45(5): 31-34. 
Miah MAT, Ahmed HU, Sharma NR, Ali A and Miah SA (1990). Antifungal activity of some plant extracts. Bangladesh Journal of Botany, 19(1): 5-10.

Patra JK and Mohanta YK (2014). Antimicrobial compounds from mangrove plants: A pharmaceutical prospective. Chinese Journal of Integrative Medicine, 20(4): 311-320.

Patra JK and Thatoi $\mathrm{H}$ (2013). Anticancer activity and chromatography characterization of methanol extract of Heritiera fomes Buch. Ham., a mangrove plant from Bhitarkanika, India. Oriental Pharmacy and Experimental Medicine, 13(2): 133-142.

Pattanaik C, Reddy CS, Dhal NK and Das R (2008). Utilization of mangrove forests in Bhitarkanika wildlife sanctuary, Orissa. Indian Journal of Traditional Knowledge, 7: 598-603.

Prashanth S, Kumar AA, Madhub B and Kumar YP (2010). Antihyperglycemic and antioxidant activity of ethanolic extract of Madhuca longifolia bark. International Journal of Pharmaceutical Sciences Review and Research, 5(3): 84-94.

Purohit R, Singh SK, Shaban A, Nautiyal R, Purohit MC and Verma SK (2012). Immunomodulatory activity of Madhuca longifolia. Der Pharmacia Sinica, 3(1): 153-155.

Rahman MS and Monowar T (2014). Toxic effects of Sapium indicum (Willd.) fruits on animal model. International Journal of Phytomedicine, 6: 310-315.

Rajbhandari M, Wegner U, Jülich M, Schoepke T and Mentel R (2001). Screening of Nepalese medicinal plants for antiviral activity. Journal of Ethnopharmacology, 74(3): 251-255.

Reddy BU (2010). Antimicrobial activity of Thevetia peruviana (Pers.) K. Schum. and Nerium indicum Linn. Internet Journal of Pharmacology, 8: 1531-1532.

Ruebhart DR, Cock IE and Shaw GR (2008). Brine shrimp bioassay: importance of correct taxonomic identification of Artemia (Anostraca) species. Environmental Toxicology, 23(4): 555. https://doi.org/10.1002/tox.20358.

Salini G (2015). Pharmacological profile of mangrove endophytes - A Review. International Journal of Pharmacy and Pharmaceutical Sciences, 7(1): 6-15.

Sara $E$ (2012). Artemia salina (L). Animal Diversity Web, University of Michigan.

Shah A, Zambare AV, Desai A and Chakraborthy GS (2011). Biological evaluations of potential herb-Nerium indicum (Linn.). International Journal of Pharmaceutical Sciences and Research, 2(2): 418-423.

Silprasit K, Seetaha S, Pongsanarakul P, Hannongbua S and Choowongkomon K (2011). Anti-HIV-1 reverse transcriptase activities of hexane extracts from some Asian medicinal plants. Journal of Medicinal Plants Research, 5(17): 4194-201.

Tewtrakul S, Tansakul P, Daengrot C, Ponglimanont C and Karalai C (2010). Anti-inflammatory principles from Heritiera littoralis bark. Phytomedicine, 17: 851-855.

Url 1. Nerium indicum. http://www.motherherbs.com/nerium-indicum.html (Accessed on: 16 October 2019).

Vinayagam A and Sudha PN (2011). Antioxidant activity of methanolic extracts of leaves and flowers of Nerium indicum. International Journal of Pharmaceutical Sciences and Research, 2: 1548-53.

(Manuscript received on 31 May 2021; revised on 11 July 2021) 